\title{
Changes in relaxin production by the theca during the preovulatory period of the pig§
}

\author{
G. Evans*, D. Claire Wathes $\dagger$, G. J. King $\ddagger$, D. T. Armstrong* and \\ D. G. Porter $\dagger$
}

*M.R.C. Group in Reproductive Biology and Departments of Physiology and of Obstetrics \& Gynaecology, University of Western Ontario, London, Ontario, Canada N6A 5A5; † Department of Anatomy, The Medical School, Bristol BS8 ITD, U.K.; and $\ddagger$ Department of Animal and Poultry Science, University of Guelph, Guelph, Ontario, Canada NIG 2W1

\begin{abstract}
Summary. Theca and granulosa layers were isolated from the preovulatory follicles of prepubertal gilts which were untreated (Group A), killed $72 \mathrm{~h}$ after 1000 i.u. PMSG (Group B), killed $84 \mathrm{~h}$ after PMSG (Group C), or killed $84 \mathrm{~h}$ after PMSG +500 i.u. hCG given at $72 \mathrm{~h}$ (Group D). The tissues from individual follicles were cultured for $24 \mathrm{~h}$ alone (C), with FSH (F) or with LH (L), and the content of immunoreactive relaxin in the culture media was measured by RIA. Concentrations of relaxin-like material were close to the limit of detection of the assay in all granulosa cell cultures, and in the thecal cultures from the untreated gilts. However, thecal cultures from all 19 treated gilts produced relaxin. The mean \pm s.e.m. concentrations (pg/follicle) in Groups AC, BC, CC and DC were $26 \cdot 5 \pm 3 \cdot 04,93 \cdot 1 \pm 4 \cdot 6,138 \pm 16.4$ and $285.6 \pm 54 \cdot 1$ respectively. Therefore relaxin production was stimulated by PMSG $(P<0.05)$, with hCG treatment in vivo leading to a further significant increase $(P<0.05)$. In-vitro treatment with gonadotrophins had no effect in Groups $\mathrm{A}, \mathrm{C}$ and D, but in Group-B gilts LH produced a significant $(P<0.05)$ rise in relaxin levels. These studies indicate that the theca is the principal source of relaxin in the porcine preovulatory follicle. The increased production before ovulation suggests that relaxin may be involved in follicular growth or rupture.
\end{abstract}

\section{Introduction}

Relaxin is present in the follicular fluid of pregnant and non-pregnant sows (Bryant-Greenwood, Jeffrey, Ralph \& Seamark, 1980; Matsumoto \& Chamley, 1980). Its presence there can be accounted for partly by diffusion from adjacent corpora lutea, the commonly recognized source of the hormone. However, the same two studies have shown that segments of follicle wall, but not isolated granulosa cells, release relaxin in vitro, suggesting that follicular biosynthesis of relaxin can occur. Small amounts of relaxin are produced by porcine granulosa cells cultured for several days in the presence of LH (Loeken, Channing, D'Eletto \& Weiss, 1983). Relaxin immunoreactivity has also been detected in human plasma around the time of ovulation in patients subjected to ovarian hyperstimulation with HMG (Thomas, Loumaye \& Ferin, 1980).

The present study was conducted (1) to determine the source of the relaxin in porcine follicles and (2) to see whether relaxin production by the follicle changed during the preovulatory period as

$\S$ Reprint requests to Dr. D. C. Wathes, Department of Anatomy, The Medical School, Bristol BS8 1TD, U.K. 
this might provide some indication of the role of relaxin in the non-pregnant pig. The prepubertal gilt has proved useful for the study of steroid biosynthesis by the isolated theca and granulosa (Evans, Dobias, King \& Armstrong, 1981) and we therefore used a similar system to examine relaxin production during follicular development and maturation.

\section{Materials and Methods}

\section{Animals}

Thirty-two (32) prepubertal Yorkshire crossbred gilts weighing $90.2 \pm 2.3 \mathrm{~kg}$ (mean \pm s.e.m.) were allocated randomly to four treatment groups: Group A, control, slaughtered without treatment; Group B, slaughtered 72 h after i.m. injection of 1000 i.u. PMSG (Equinex: Ayerst Laboratories, Montreal); Group C, slaughtered $84 \mathrm{~h}$ after 1000 i.u. PMSG; Group D, slaughtered at $84 \mathrm{~h}$ after injection of 1000 i.u. PMSG, with 500 i.u. hCG (A.P.L.: Ayerst) administered i.m. at $72 \mathrm{~h}$. The treatment for Group D normally results in ovulation $\sim 42 \mathrm{~h}$ after hCG, with a small degree of superovulation (Baker \& Coggins, 1968; Baker, Mellish \& Segal, 1969), of meiotically mature oocytes from steroidogenically active follicles (Ainsworth, Tsang, Downey, Marcus \& Armstrong, 1980; Evans et al., 1981).

\section{Culture technique}

Ovaries were collected immediately after slaughter, washed and kept on ice in Eagle's Minimal Essential Medium buffered with Hepes. Theca tissue (interna + externa) and granulosa cells were isolated and cultured for $24 \mathrm{~h}$ as described previously (Evans et al., 1981) with the following differences. Tissue was cultured in $1 \mathrm{ml}$ medium containing no hormones (control), $0.5 \mu \mathrm{g} \mathrm{FSH}$ (NIH-FSH-S11) or $0.5 \mu \mathrm{g} \mathrm{LH} \mathrm{(NIH-LH-B4);} \mathrm{doses} \mathrm{of} \mathrm{hormones} \mathrm{in} \mathrm{this} \mathrm{range} \mathrm{are} \mathrm{known} \mathrm{to}$ stimulate steroid production in vitro in these circumstances (Evans et al., 1981). Each in-vitro treatment was replicated 4 times. One follicle-equivalent of tissue (theca or granulosa separately) was added to each culture well, except for some animals from which $<16$ follicles were obtained; in such cases, the same degree of minor replication was maintained by adding proportionately less tissue to each culture dish and correcting the results of relaxin analyses accordingly. Samples of medium were cultured with hormones but without tissue, as appropriate controls. Samples of tissue were reserved without culture for estimation of initial content of relaxin. These were acidified with $0.2 \mathrm{ml} \mathrm{50 \%} \mathrm{acetic} \mathrm{acid} \mathrm{and} \mathrm{freeze-dried.} \mathrm{Dissections} \mathrm{were} \mathrm{complete} \mathrm{and} \mathrm{culture} \mathrm{begun} \mathrm{within}$ $8-10 \mathrm{~h}$ of slaughter.

Immediately after culture, media were collected and kept at $-20^{\circ} \mathrm{C}$. All samples were freezedried for transportation to England for assay.

\section{Relaxin radioimmunoassay}

Porcine relaxin was measured by an homologous radioimmunoassay as described by Taverne $e t$ al. (1982). The highly-purified relaxin standard (CMy) used in this assay was extracted from the ovaries of pregnant sows (Taverne et al., 1982). Freeze-dried samples of culture medium were reconstituted in assay buffer $(0.05 \mathrm{M}$-sodium barbitone $\mathrm{pH} 8.5$ containing $50 \%$ inactivated horse serum) and were measured in triplicate at two dilutions. These showed parallelism with the standard curve (Text-fig. 1). For the acidified tissue samples, $0.8 \mathrm{ml}$ assay buffer was added to the freeze-dried material and vortexed and the supernatant was assayed as above. The sensitivity of the assay was $4.5 \mathrm{pg}$ per tube. The inter- and intra-assay coefficients of variation were $13.7 \%$ and $6.3 \%$ respectively. Freeze drying of samples was previously shown not to alter their relaxin content. 


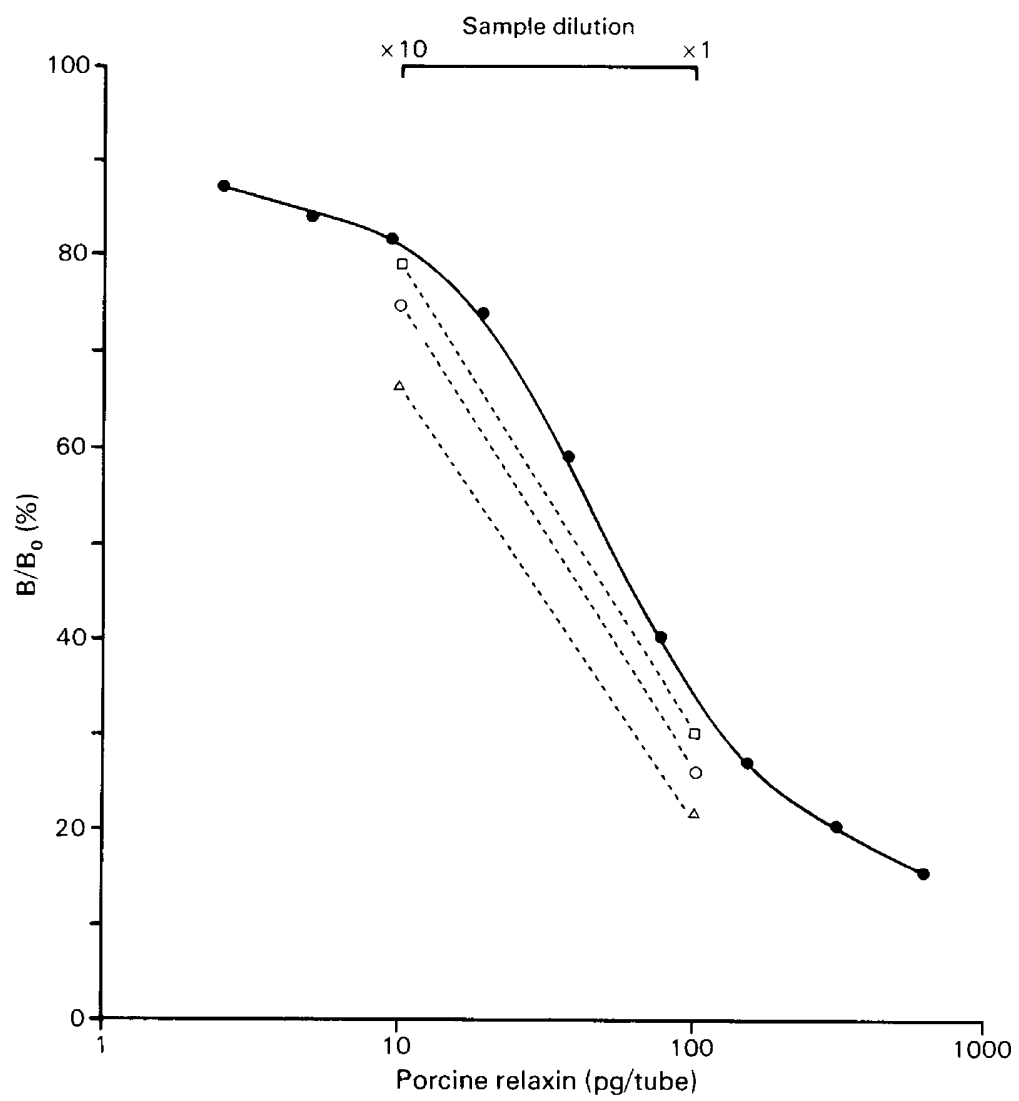

Text-fig. 1. Porcine relaxin radioimmunoassay standard curve: standard prepartions, ---3 different medium samples from thecal cultures $(\square, O, \triangle)$, each assayed at two dilutions.

\section{Protein determination}

Freeze-dried tissue samples were reconstituted in $1 \mathrm{ml} 1 \%$ sodium dodecyl sulphate and the protein in each sample was measured by the method of Lowry, Rosebrough, Farr \& Randall (1951) using bovine serum albumin as a standard.

\section{Statistical analyses}

Ovaries were rejected if they had not responded to PMSG treatment (infantile, or did not possess large follicles) or if they had signs of previous ovulations. In addition there was accidental loss of some samples. In combination, this resulted in data being obtained from 7 animals in Group A, 4 in Group B, 8 in Group C and 7 in Group D.

The data were analysed for theca and granulosa separately by analysis of variance, using an unbalanced design. A logarithmic transformation was required to eliminate heterogeneity of variance but, for convenient appraisal, the data are presented in untransformed form. Duncan's Multiple Range Test was used to compare specific main effect means. A probability level of $P<0.05$ was regarded as significant. 


\section{Results}

Results presented herein represent accumulation of relaxin in medium per follicle equivalent of tissue over a 24-h culture period. Samples of medium 'blanks' containing FSH or LH but no tissue and also cultured for $24 \mathrm{~h}$ had relaxin assay values close to the limits of detection and no corrections were made. The initial content of relaxin in representative samples of tissue before culture is shown in the figures but has not been subtracted from total accumulation in the medium. The final tissue content of relaxin (after culture) was not measured; the accumulation of relaxin in medium may therefore represent less than the total amount synthesized in culture. The average protein content of representative follicles at 0,72 and $84 \mathrm{~h}$ after PMSG injection was: for granulosa 259, 472 and $427 \mu \mathrm{g}$ respectively; for theca 357,657 and $744 \mu \mathrm{g}$ respectively. Since protein content was not measured for each cultured tissue the results have not been corrected for slight variations in quantity of tissue per culture well.

\section{Granulosa cell relaxin production}

The production of relaxin by granulosa cells at each stage of follicular development is represented in Text-fig. 2(a). The initial content of relaxin in tissue was below the limit of detection of the assay for many samples and, in general, the relaxin accumulation in media was close to the limits of detection. There was no significant effect of in-vivo treatment on relaxin accumulation nor was there any effect of in vitro hormone treatment.

\section{Theca tissue relaxin production}

As shown in Text-fig. 2(b) there was a significant effect $(P<0.001)$ of in-vivo treatment (Group) on relaxin production; there was an increase in production in Groups B and C compared with Group A controls ( 72 and $84 \mathrm{~h}$ after PMSG; $P<0.05$ ), with even greater production in Group $\mathrm{D}(P<0.05)$ due to administration of hCG in vivo at $72 \mathrm{~h}$ after PMSG. There was no overall effect of adding FSH or LH to culture in vitro, but in Group B LH increased relaxin production $(P<0.05)$.

\section{Discussion}

Relaxin is generally considered to be a hormone produced by the corpus luteum during pregnancy. However, it has been isolated from the follicular fluid of pregnant and non-pregnant sows, and it is also present in animals with polycystic ovaries (Bryant-Greenwood et al., 1980; Matsumoto \& Chamley, 1980). Bryant-Greenwood et al. (1980) showed that although follicular relaxin levels tend to be higher in ovaries containing corpora lutea, suggesting diffusion from this source, segments of follicle wall will continue to release relaxin into the medium over a 4-day culture period indicating that the follicle is itself capable of relaxin biosynthesis. Although Loeken et al. (1983) have reported low-level relaxin secretion by granulosa cells isolated from large porcine follicles and cultured for several days in the presence of $\mathrm{LH}$, they needed to concentrate their medium before the relaxin levels were measurable and neither Matsumoto \& Chamley (1980) nor Bryant-Greenwood et al. (1980) could detect relaxin in cultures of isolated porcine granulosa cells. We were likewise unable to measure relaxin production by the granulosa much in excess of the limits of detection of the assay, and there was no stimulation by PMSG or hCG in vivo or FSH or LH in vitro at doses which normally evoke steroidogenic responses.

Our study indicates for the first time that it is the theca rather than the granulosa which is the major source of relaxin in porcine follicles. We also show that there is a significant increase in relaxin production by the theca as the time of ovulation approaches. This was initially stimulated in 


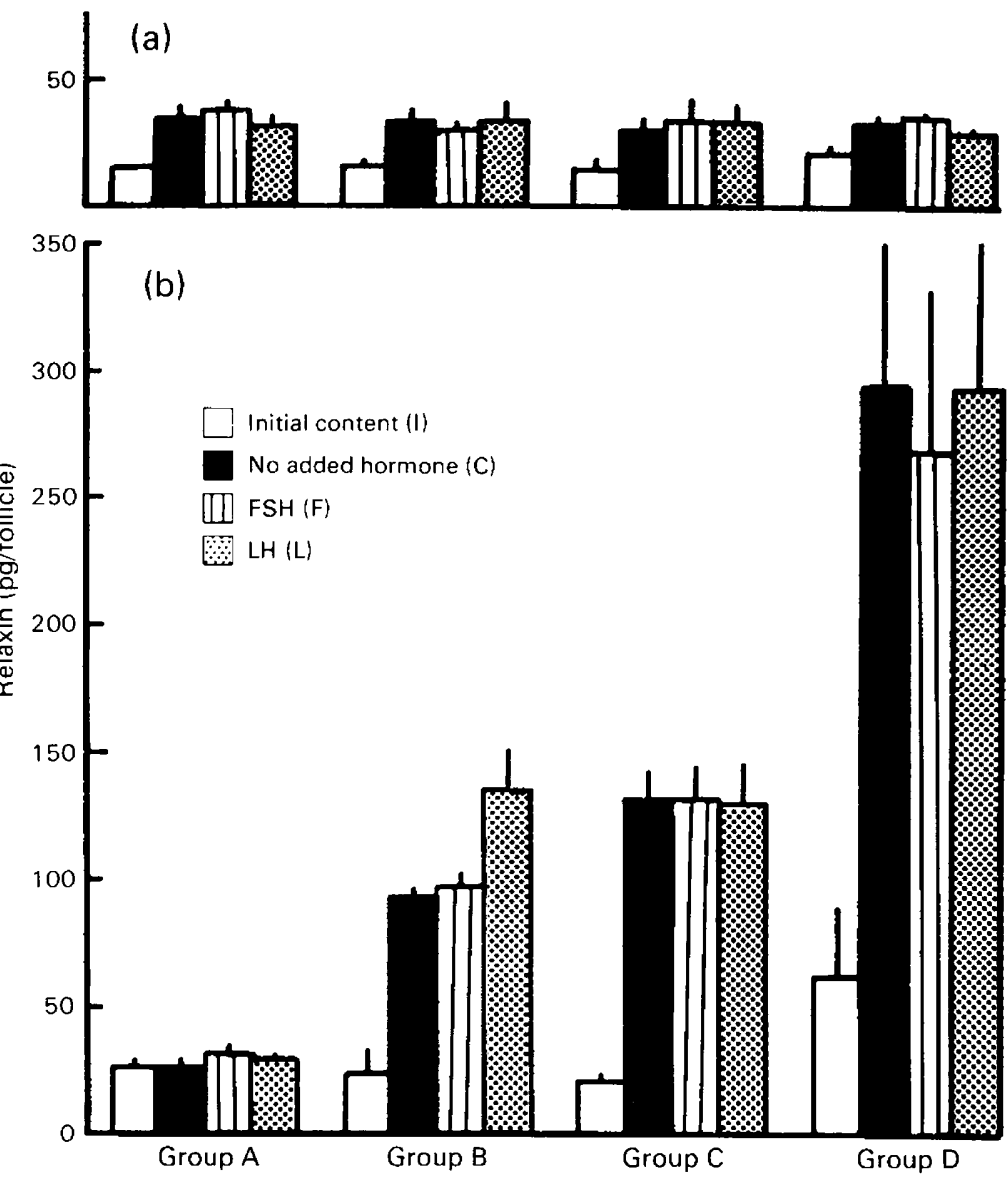

Text-fig. 2. In-vitro production of relaxin by porcine granulosa cells (a) and theca tissue (b), measured as accumulation of relaxin per follicle equivalent of tissue in media after $24 \mathrm{~h}$ culture in the presence of no added hormone (C), $0.5 \mu \mathrm{g} \mathrm{FSH} / \mathrm{ml}(\mathrm{F})$ or $0.5 \mu \mathrm{g} \mathrm{LH} / \mathrm{ml}(\mathrm{L})$. The initial content of relaxin in the tissue before culture is also shown (I). Some of these values were below the limit of detection of the assay in which case the limit of detection was used in calculating the means. The in-vivo treatments were: Group A, controls (no in-vivo treatment); Group B, slaughter $72 \mathrm{~h}$ after PMSG; Group C, slaughter $84 \mathrm{~h}$ after PMSG; and Group D, slaughter $84 \mathrm{~h}$ after PMSG with hCG at $72 \mathrm{~h}$ (see 'Materials and Methods').

vivo with PMSG, but a further increase in output in vitro occurred from ovaries after hCG injection in vivo. In-vitro treatment with $\mathrm{LH}$ was only effective $72 \mathrm{~h}$ after PMSG, whereas FSH treatment in vitro did not alter relaxin production at any of the times studied. It therefore remains unclear whether the in-vivo injections of PMSG and hCG acted directly to enhance relaxin release, or whether some intermediate factors were involved. For example, Evans et al. $(1981 ; 1983)$ have shown that a similar treatment regimen alters both the steroid and prostaglandin secretion patterns of the theca and granulosa and these changes could in turn influence relaxin production.

As the follicular capacity to release relaxin increases near the time of ovulation it seems likely that relaxin is involved in this process (see Bryant-Greenwood, 1982). One possible role for relaxin could be in the dissolution of the follicle wall and the release of the cumulus oöphorus. The tunica albuginea and the theca externa of the pig contains an extensive network of collagen fibrils (Corner, 1919; Espey, 1967a). In the hours preceding ovulation this framework undergoes physiological deterioration resulting in a marked decrease in the tensile strength of the follicle wall 
(Espey, 1967b). Chihal \& Espey (1973) have shown that the ultrastructural changes in the collagen fibres of the pubic symphysis of the guinea-pig during relaxin-induced inter-innominate pubic ligament formation resemble very closely those observed in follicular collagen just before ovulation. Proteolytic enzymes may also be important for the disruption of the follicle wall (Schochet, 1916; Espey, 1974). It is now thought that the production of plasminogen activator by ripening follicles is at least one of the key factors in this process (Strickland \& Beers, 1979; Espey, 1980). The demonstration that relaxin can bring about a dose-related rise in the secretion of plasminogen activator by cultured rat granulosa cells indicates that relaxin may be one of the many factors involved in the control of these events (Too, Weiss \& Bryant-Greenwood, 1982).

Smooth muscle is present in the hilar and medullary regions of the mammalian ovary and it has been reported to occur in the theca externa of several species, including the sow (Corner, 1919; Guttmacher \& Guttmacher, 1921). In their detailed study of the hamster ovary, Martin \& Talbot, $1981 \mathrm{a}, \mathrm{b})$ show that the theca externa only contracts in the last few minutes before ovulation, when the base of the follicle is pushed upwards. Smooth muscle tends to contract in response to stretch, so that, by relaxing muscle cells in the theca externa during the preovulatory period, relaxin could allow the follicle to expand rapidly at this time whilst preventing premature contraction.

The classic work of Corner (1919) showed clearly that both the theca and granulosa contribute to the formation of the corpus luteum in the sow and this has been confirmed ultrastructurally (Cavazos et al., 1969). Both papers suggest that the granulosa layer gives rise to the large (granulosa) lutein cells, whereas the theca interna forms the small (theca) lutein cells. Three separate reports on the localization of relaxin within the corpus luteum of the pregnant sow all state that the peptide is found in granulosa lutein cells, whilst omitting any reference to the presence of theca lutein cells (Belt, Cavazos, Anderson \& Melampy, 1971; Larkin, Fields \& Oliver, 1977; Kendall, Plopper \& Bryant-Greenwood, 1978). However, our results with cultured follicular tissue indicate that in the preovulatory follicle it is the theca rather than the granulosa which secretes relaxin. If the same cell line continues to make the same peptide hormone after ovulation this would imply that the small theca-derived cells can become large luteal cells. In 1966, following a study of the bovine corpus luteum Donaldson \& Hansel wrote "The granulosa-derived luteal cells develop into functioning luteal cells by about Day 4 of the estrous cycle, after which they undergo no further divisions. Therefore granulosa-derived cells have limited potential. However the smaller luteal cells derived from the theca interna respond to plasma luteotropin, multiply and grow into large luteal cells. These are mainly responsible for the growth of the corpus luteum following Day 4". As no-one has yet labelled preovulatory theca or granulosa cells and followed their subsequent fate this hypothesis has not been tested. However, our data on relaxin suggest that it may be correct.

We thank Mrs S. Somers for typing the manuscript; Ms B. Atkinson, Ms N. Colvin, Miss J. Creek, Mr. R. Jones, Miss A. Moffatt, Ms S. Mulholland, Ms A. Rouleau-Coulter for skilled technical assistance; and the NIH Hormone Distribution Office (U.S.A.) for the LH and FSH. The work was supported in parts by grants from the A.R.C. (AG7/103), the M.R.C. (U.K.) (G 8011540 SA), the M.R.C. (Canada) and the Ontario Ministry of Agriculture and Food. D.T.A. is a career Investigator of the M.R.C. (Canada).

\section{References}

Ainsworth, L., Tsang, B.K., Downey, B.R., Marcus, G.J. \& Armstrong, D.T. (1980) Interrelationships between follicular fluid steroid levels, gonadotropic stimuli, and oocyte maturation during preovulatory development of porcine follicles. Biol. Reprod. 23, 621-627.

Baker, R.D. \& Coggins, E.G. (1968) Control of ovulation rate and fertilization rate in prepubertal gilts. $J$. Anim. Sci. 27, 1607-1610.
Baker, R.D., Meliish, K.S. \& Segal, D.H. (1969) First polar body formation and ovulation in gilts. J. Anim. Sci. 29, 183, Abstr.

Belt, W.D., Cavazos, L.F., Anderson, L.L. \& Melampy, R.M. (1971) Cytoplasmic granules and relaxin levels in porcine corpora lutea. Endocrinology 89, 1-10.

Bryant-Greenwood, G.D. (1982) Relaxin as a new hormone. Endocrine Reviews 3, 62-90. 
Bryant-Greenwood, G.D., Jeffrey, R., Ralph, M.M. \& Seamark, R.F. (1980) Relaxin production by the porcine ovarian Graafian follicle in vitro. Biol. Reprod. 23, 792-800.

Cavazos, L.F., Anderson, L.L., Belt, W.D., Henricks, D.M., Kraeling, R.R. \& Melampy, R.M. (1969) Fine structure and progesterone levels in the corpus luteum of the pig during the estrous cycle. Biol. Reprod. 1, 83-106.

Chihal, H.J. \& Espey, L.L. (1973) Utilization of the relaxed symphysis of guinea pigs for clues of the mechanism of ovulation. Endocrinology 93, 14411444.

Corner, G.W. (1919) On the origin of the corpus luteum of the sow from both granulosa and theca interna. Am. J. Anat. 26, 117-183.

Donaldson, L. \& Hansel, W. (1966) Histological study of bovine corpora lutea. J. Dairy Sci. 48, 905-909.

Espey, L.L. (1967a) Ultrastructure of the apex of the rabbit Graafian follicle during the ovulatory process. Endocrinology 81, 267-276.

Espey, L.L. (1967b) Tenacity of porcine Graafian follicle as it approaches ovulation. Am. J. Physiol. 212, 13971401.

Espey, L.L. (1974) Ovarian proteolytic enzymes and ovulation. Biol. Reprod. 10, 216-235.

Espey, L.L. (1980) Ovulation as an inflammatory reaction-a hypothesis. Biol. Reprod. 22, 73-106.

Evans, G., Dobias, M., King, G.J. \& Armstrong, D.T. (1981) Estrogen, androgen and progesterone biosynthesis by theca and granulosa of preovulatory follicles in the pig. Biol. Reprod. 25, 673-682.

Evans, G.D., Dobias, M., King, G.J. \& Armstrong, D.T. (1983) Production of prostaglandins by porcine preovulatory follicular tissues and their roles in intrafollicular function. Biol. Reprod. 28, 322-328.

Guttmacher, M.S. \& Guttmacher, A.F. (1921) Morphological and physiological studies on the musculature of the mature Graafian follicle of the sow. Johns Hopkins Hosp. Bull. 32, 394-399.

Kendall, J.Z., Plopper, C.G. \& Bryant-Greenwood, G.D. (1978) Ultrastructural immunoperoxidase demonstration of relaxin in corpora lutea from a pregnant sow. Biol. Reprod. 18, 94-98.
Larkin, L.H., Fields, P.A. \& Oliver, R.M. (1977) Production of antisera against electrophoretically separated relaxin and immunofluorescent localization of relaxin in the porcine corpus luteum. Endocrinology 101, 679-685.

Loeken, M.R., Channing, C.P., D'Eletto, R. \& Weiss, G. (1983) Stimulatory effect of luteinizing hormone upon relaxin secretion by cultured porcine preovulatory granulosa cells. Endocrinology 112, 769-771.

Lowry, O.H., Rosebrough, N.J., Farr, A.L. \& Randall, R.J. (1951) Protein measurement with the Folin phenol reagent. J. biol. Chem. 193, 265-275.

Martin, G.G. \& Talbot, P. (1981a) The role of follicular smooth muscle cells in hamster ovulation. $J$. exp. Zool. 216, 469-482.

Martin, G.G. \& Talbot, P. (1981b) Drugs that block smooth muscle contraction inhibit in vivo ovulation in hamsters. J. exp. Zool. 216, 483-491.

Matsumoto, D. \& Chamley, W.A. (1980) Identification of relaxins in porcine follicular fluid and in the ovary of the immature sow. J. Reprod. Fert. 58, 369-375.

Schochet, S.S. (1916) A suggestion as to the process of ovulation and ovarian cyst formation. Anat. Rec. 10, 447-457.

Strickland, S. \& Beers, W.H. (1979) Studies of the enzymatic basis and hormonal control of ovulation. In Ovarian Follicular Development and Function, pp. 143-153. Eds A. R. Midgley \& W. A. Sadler. Raven Press, New York.

Taverne, M., Bevers, M., Bradshaw, J.M.C., Dieleman, S.J., Willemse, A.H. \& Porter, D.G. (1982) Plasma concentrations of prolactin, progesterone, relaxin and oestradiol $17 \beta$ in sows treated with progesterone, bromocriptine or indomethacin during late pregnancy. J. Reprod. Fert. 65, 85-96.

Thomas, K., Loumaye, E. \& Ferin, J. (1980) Relaxin in non-pregnant women during ovarian stimulation. Gynecol. obstet. Invest. 11, 75-80.

Too, C.K.L., Weiss, T.J. \& Bryant-Greenwood, G.D. (1982) Relaxin stimulates plasminogen activator secretion by rat granulosa cells in vitro. Endocrinology 111, 1424-1426.

Received 13 April 1983 